\title{
Peningkatan Pemahaman Masyarakat Tentang Pemanfaatan Herbal Sebagai Terapi Penunjang Diabetes Mellitus dan Hipertensi Di Wilayah Kampung Windan
}

\author{
${ }^{1}$ Anita Sukmawati*, ${ }^{1}$ Lintang Titian Cahya, ${ }^{1}$ Purbandari Ajeng Sarweningtyas, ${ }^{1}$ Lintang \\ Karengga Ihsani, ${ }^{1}$ Muhammad Bakthiar, ${ }^{1}$ Palupi Finofasipa, ${ }^{1}$ Oktavia Permata Fenthiadewi \\ ${ }^{1}$ Fakultas Farmasi, Universitas Muhammadiyah Surakarta \\ *Penulis korespondensi, email: anita.sukmawati@ums.ac.id
}

(Received: 21 July 2021/Accepted: 28 July 2021/Published: 31 July 2021)

\begin{abstract}
Abstrak
Penyakit diabetes mellitus (DM) dan hipertensi merupakan penyakit dengan angka kejadian yang tinggi di Indonesia maupun dunia. Berdasarkan informasi yang diperoleh bahwa warga Kampung Windan, Kelurahan Makamhaji, Kabupaten Sukoharjo, banyak yang menderita penyakit diabetes melitus (DM) dan hipertensi sehingga memerlukan pengetahuan terkait pemanfaatan tanaman sebagai herbal untuk terapi DM dan hipertensi. Tujuan dari kegiatan ini adalah peningkatan pemahaman masyarakat terkait penggunaan herbal untuk terapi pada penyakit DM dan hipertensi.

Kegiatan penyuluhan ini ditargetkan kepada ibu-ibu anggota PKK Kampung Windan RT 1 RW 8 Makamhaji sebagai peserta. Materi yang diberikan berupa pemanfaatan tanaman atau bahan yang mudah ditemukan dimasyarakat sekitar untuk dimanfaatkan sebagai terapi DM dan hipertensi. Penyampaian materi dilakukan dengan presentasi oral/ceramah dan brosur yang dibagikan kepada peserta. Tingkat pemahaman peserta diukur dengan memberikan beberapa pertanyaan pada awal (pre-test) dan akhir (post-test) kegiatan penyuluhan pada 23 peserta penyuluhan.

Hasil kegiatan menunjukkan bahwa adanya pemberian materi berupa ceramah dan brosur dapat meningkatkan pemahaman masyarakat terkait penggunaan herbal untuk terapi penunjang DM dan hipertensi yang ditunjukkan dengan adanya peningkatan nilai rata-rata nilai pre test dan post test sebesar $11 \%$ dan nilai signifikansi $(p)<0.05$. Berdasarkan hasil pre-test dan post-test disimpulkan bahwa kegiatan pemberian ceramah dan brosur secara bermakna dapat meningkatkan pemahaman peserta terkait penggunaan herbal untuk terapi penyakit degeneratif seperti hipertensi dan DM.
\end{abstract}

Kata Kunci : brosur, ceramah, diabetes, hipertensi, tanaman obat

\begin{abstract}
Diabetes mellitus (DM) and hypertension are diseases with a high incidence in Indonesia and the world. Based on the information obtained, many residents of Windan Village, Makamhaji Village, Sukoharjo Regency, suffer from diabetes mellitus (DM) and hypertension, so they need knowledge related to the use of plants as herbs for DM and hypertension therapy. The purpose of this activity is to increase public understanding regarding the use of herbs for therapy in DM and hypertension.

This activity was targeted for PKK members of Kampung Windan RT 1 RW 8 Makamhaji as participants. The material provided in this activity was related to the use of herbal or subtances, that are easily found in the surrounding community, to be used as a therapy for DM and hypertension. The material was delivered through oral presentations/lecture and brochur which distributed to participants. The level of understanding of the participants was measured by giving
\end{abstract}


several questions at the beginning (pre-test) and at the end (post-test) of the extension activities to 23 participants.

The results of the activity showed that delivery of materials using lecture method and brochure could increase participants understanding regarding the use of herbs for treating diabetes mellitus and hypertension as indicated by an increase in average value of pre-test and post-test by $11 \%$ and significance value $(p)<0.05$. Based on the results of the pre-test and post-test, it was concluded that the activities including lecture and brochure could significantly increase the participants understanding regarding the use of herbs for the treatment of degenerative diseases such as hypertension and DM.

Keywords : brochure, lecture, diabetes, hypertension, herbal medicines

\section{Pendahuluan}

Kampung Windan RT 1 RW 8 Makamhaji merupakan wilayah yang terletak di kelurahan Kartasura, Kecamatan Kartasura, Sukoharjo dengan penduduk yang terdiri dari berbagai latar belakang Pendidikan. Mayoritas penduduk kampung ini berpendidikan Sekolah Menengah (SMP dan SMA). Latar belakang pekerjaan warga Windan yaitu pegawai, buruh dan ibu rumah tangga dengan tingkat penghasilan menengah ke bawah. Para ibu di Kampung Windan RT 1 RW 8 secara rutin mengadakan kegiatan PKK (Pemberdayaan Kesejahteraan Keluarga) yang bertujuan untuk meningkatkan kesejahterahan keluarga dan sebagai sarana silahturahmi antar warga didaerah tersebut. Program PKK sendiri merupakan suatu kegiatan yang memiliki tujuan memberdayakan keluarga untuk meningkatkan kesejahteraan keluarga. Sasaran program ini menghimpun, menggerakan dan membina potensi masyarakat untuk terlaksananya program pemberdayaan sesuai kebutuhan masyarakat (Peraturan Menteri Dalam Negeri Republik Indonesia Nomor 36 Tahun 2020, 2020).

Informasi yang diperoleh dari wawancara dengan salah satu warga di daerah tersebut menyebutkan bahwa kegiatan PKK yang dilakukan setiap bulan belum dapat dilaksanakan dengan optimal sesuai dengan sasaran kelompok kerja PKK. Hal ini dikarenakan keterbatasan kemampuan dan keilmuan para ibu anggota PKK dan minimnya sarana dan prasarana di perkumpulan PKK tersebut. Kegiatan yang telah dilakukan selama ini terbatas pada penyelenggaraan kegiatan bulanan seperti arisan. Oleh karena itu, diperlukan upaya-upaya lain untuk meningkatkan pengetahuan ibu-ibu PKK khususnya di bidang kesehatan. Adanya peningkatan pengetahuan terkait bidang kesehatan maka diharapkan dapat menumbuhkan kesadaran akan pentingnya menjaga kesehatan dan mencegah terjadinya penyakit.

Dari hasil survey awal, diperoleh informasi bahwa warga Kampung Windan banyak yang menderita penyakit diabetes melitus (DM) dan hipertensi. Kedua penyakit ini sering muncul bersamaan dan merupakan penyakit yang dipengaruhi oleh gaya hidup, pola makan, aktivitas, dan kondisi sosial. Terdapat tumpeng tindih antara etiologi dan mekanisme penyebab DM dan hipertensi, antara lain kegemukan, stress oksidatif, inflamasi dan resistensi insulin. Kedua penyakit ini juga dapat memicu terjadinya aterosklerosis, serangan jantung dan stroke. Oleh karena itu, modifikasi gaya hidup merupakan upaya untuk mencegah dan mengobati penyakit DM dan hipertensi (Cheung \& Li, 2012).

Keadaan DM digambarkan sebagai penyakit metabolik yang menyebabkan tingginya kadar gula dalam darah yang disebabkan karena kekurangan insulin (DM tipe 1) dan atau resistensi terhadap insulin (DM tipe 2). Penyakit DM tipe 2 telah menjadi isu global dibeberapa negara dan menyebabkan tingginya angka kematian (Tayyab Akhtar et al., 2016). Keadaan hipertensi digambarkan sebagai keadaan dengan tekanan darah yang meningkat diatas $120 \mathrm{mmHg}$ (sistolik) dan diatas $80 \mathrm{mmHg}$ (diastolik). Menurut American Heart Association (AHA), hipertensi dapat dikategorikan menjadi beberapa sub klasifikasi antara lain stage 1, 2 dan krisis hipertensi (Barhum, 2019). Penyebab hipertensi sendiri dapat digolongkan menjadi penyebab esensial dan sekunder. Penyebab esensial hipertensi antara lain disebabkan oleh adanya stress, obesitas, hypokalemia, dan kekurangan vitamin D. Resiko ini semakin meningkat dengan 
bertambahnya usia. Selain itu, adanya penyakit metabolik seperti gangguan ginjal dan resistensi insulin juga dapat memicu terjadinya hipertensi. Sedangkan penyebab sekunder dari hipertensi adalah ketidakseimbnagan hormon yang disebabkan oleh kehamilan, hyper atau hipotiroid dan adanya kanker kelenjar adrenal (Tabassum \& Ahmad, 2011).

Pengobatan DM dan hipertensi dapat dilakukan menggunakan obat-obatan sesuai dengan panduan pengobatan DM dan hipertensi. Selain menggunakan obat-obatan sintetik, beberapa tanaman juga dilaporkan memiliki aktivitas anti diabetes dan anti hipertensi, sehingga dapat digunakan sebagai alternatif atau terapi pelengkap. Pengobatan menggunakan tanaman atau herbal saat ini sangat didukung oleh banyaknya penelitian ilmiah terkait hal ini. Tanaman juga mengandung beberapa konstituen fitoterapi seperti flavonoid, terpenoid, saponin, alkaloid, glikosida yang dapat mendukung pengobatan. Selain itu, penggunaan tanaman herbal untuk pengobatan relatif tidak menimbulkan toksisitas dan tidak menimbulkan efek samping (Salehi et al., 2019; Tabassum \& Ahmad, 2011).

Pengobatan DM menggunakan tanaman obat atau herbal dilakukan dengan berbagai mekanisme kerja, antara lain dengan meningkatkan sekresi insulin, meningkatkan sensisitivitas terhadap insulin, menghambat produksi glukosa dari hati, meningkatkan uptake glukosa pada jaringan lemak dan otot, dan mengatasi komplikasi yang terjadi akibat diabetes (Li et al., 2012). Beberapa tanaman yang diketahui memiliki aktivitas antidiabetes antara lain sambiloto (Andrographis paniculate (Burm.f)), daun salam (Syzygium polyanthum (Wight)) dan temulawak (Curcuma xanthorrhiza) (Salleh et al., 2016; Tayyab Akhtar et al., 2016; Widyawati et al., 2015). Khasiat herbal tersebut sebagai obat untuk DM juga telah didukung oleh beberapa penelitian terkait kandungan dan mekanisme aksi dari bahan aktif yang terkandung dalam tanaman.

Penggunaan herbal untuk pengobatan hipertensi juga telah dipraktekkan secara empiris di masyarakat. Penggunaan herbal sebagai antihipertensi tidak hanya ditemukan di Indonesia. Penelitian yang dipaparkan oleh Hughes et. al (2013), menunjukkan bahwa penggunaan herbal sebagai antihipertensi juga dilakukan oleh masyarakat di Afrika Selatan sebagai terapi alternatif yang dianggap lebih aman dan murah dibandingkan penggunaan obat sintetik. Selain itu, obat yang berasal dari tanaman dianggap lebih mudah untuk didapatkan pada area tempat tinggal seperti yang diungkapkan pada penelitian oleh Neamsuvan et al., (2018) terkait penggunaan herbal untuk pengobatan hipertensi di Propinsi Songkhla, Thailand. Tanaman obat atau herbal ini sebagian besar digunakan dengan cara direbus dengan air (78\%) dan diminum 3 kali sehari sebelum makan (26\%) (Neamsuvan et al., 2018). Beberapa tanaman yang memiliki khasiat sebagai anti hipertensi antara lain buah mengkudu (Morinda citrifolia, L), bawang putih (Allium sativum, L), daun salam (Syzygium polyanthum (Wight) dan rimpang kunyit (Curcuma longa) (Leong, 2018; Neamsuvan et al., 2018; Ribeiro et al., 2014) dengan berbagai macam kandungan bahan berkhasiat dan mekanisme aksi.

Penggunaan herbal untuk pengobatan DM dan hipertensi perlu dilakukan dengan metode yang efektif agar informasi dapat tersampaikan dengan baik kepada anggota PKK Kampung Windan. Profil tingkat pendidikan target audiens yang sangat heterogen menjadi tantangan tersendiri dalam menyampaikan informasi. Untuk itu diperlukan strategi yang efektif dalam menyampaikan informasi terkait penggunaan tanaman untuk pengobatan DM dan hipertensi, yaitu menggunakan metode ceramah dengan media slide bergambar dan juga brosur berisi informasi terkait penggunaan tanaman untuk pengobatan DM dan hipertensi.

Metode ceramah merupakan metode konvensional untuk menyampaikan informasi karena metode ini dianggap sebagai metode yang paling praktis dan ekonomis. Metode ini memiliki kelebihan yaitu kendali audiens dapat dengan mudah dilakukan oleh pemberi materi, proses pembelajaran lebih mudah dilakukan dan dapat diikuti oleh banyak peserta. Tetapi metode ini memiliki beberapa kekurangan antara lain peserta menjadi pasif, kegiatan membosankan dan lebih fokus pada pengertian kata-kata saja (Pawiro, 2019). Untuk lebih meningkatkan efektifitas penyampaian informasi, maka metode ceramah ini dikombinasikan dengan penggunaan slide power point dan juga brosur berisi informasi yang akan disampaikan. 
Penggunaan slide power point dapat digunakan untuk menampilkan informasi secara visual. Keuntungan lain dari metode ini adalah media informasi dapat disimpan sebagai catatan digital yang dapat digunakan selanjutnya (Warnars, 2006). Dalam hal ini, media power point dapat digunakan untuk menampilkan tulisan dan gambar terkait materi yang diberikan, sehingga audiens lebih mudah untuk mengikuti pemaparan materi. Selain pemanfaatan media power point, digunakan juga media brosur untuk penyampaian informasi dengan harapan brosur informasi dapat dibaca ulang oleh audiens setelah selesai acara dan dapat disebarluaskan pada anggota keluarga yang lain. Brosur adalah suatu bentuk publikasi singkat yang berisi keternagan untuk diketahui secara umum. Brosur biasanya dicetak dengan warna yang menarik untuk meningkatkan daya tarik brosur (Ramadhan et al., 2018). Brosur dapat digunakan sebagai bagian dari kegiatan komunikasi persuasif mengenai informasi kegiatan atau dapat berdiri sendiri tanpa tergantung adanya kegiatan. Isi brosur sebagai media komunikasi dapat dikategorikan berdasarkan 3 aspek yaitu aspek informasi, aspek edukatif dan aspek persuasif dengan bobot tiap aspek yang tergantung dari kebutuhan dan tujuan penyebaran brosur (Silvana \& Rohanda, 2017).

Berdasarkan analisis situasi, dapat diidentifikasi permasalahan yang ada yaitu belum optimalnya kegiatan PKK rutin yang diadakan di Kampung Windan karena keterbatasan pengetahuan keilmuan anggota PKK serta perlunya pemberian informasi terkait pemanfaatan tanaman untuk pengobatan DM dan hipertensi. Untuk memecahkan masalah ini, perlu dilakukan upaya untuk memberikan informasi terkait dengan penggunaan tanaman berkhasiat obat. Metode yang digunakan dalam penyampaian informasi adalah melalui ceramah dan pemberian brosur informasi terkait tanaman berkhasiat untuk pengobatan DM dan hipertensi. Tujuan kegiatan ini adalah untuk peningkatan pemahaman masyarakat Kampung Windan, khusunya ibu-ibu anggota PKK terhadap pemanfaatan tanaman untuk pengobatan dan terapi penunjang untuk DM dan hipertensi. Kegiatan ini diharapkan dapat bermanfaat untuk meningkatkan pengetahuan masyarakat terkait tanaman berkhasiat obat sehingga dapat diaplikasikan dalam kehidupan seharihari.

\section{Metode}

Kegiatan ini dilaksanakan bersamaan dengan kegiatan rutin PKK yang dilakukan di Kampung Windan. Penyampaian informasi terkait pemanfaatan tanaman untuk pengobatan DM dan hipetensi dilakukan dengan metode ceramah didukung dengan media slide power point dan brosur. Pengukuran pemahaman dilakukan melalui mekanisme pre-test di awal acara dan posttest diakhir acara. Tahapan yang dilalui dalam kegiatan ini dapat dijelaskan pada uraian berikut ini.

a. Pre-test

Pre-test diberikan untuk mengukur pengetahuan dasar dari peserta penyuluhan dan dilakukan secara tertulis. Peserta penyuluhan diberikan beberapa pertanyaan dalam bentuk multiple choice questions (MCQ) terkait dengan materi yang akan diberikan. Pertanyaan yang diberikan yaitu terkait identitas peserta, usia peserta, pengetahuan terkait dengan penyakit DM dan hipertensi, tanaman yang dapat digunakan untuk pengobatan penyakit DM dan hipertensi, serta terapi non farmakologis untuk penyakit DM dan hipertensi.

b. Pemberian Materi

Pemberian materi dilakukan dengan 2 metode, yaitu metode ceramah dan pemberian brosur. Tahap pertama adalah pemberian materi dengan metode ceramah dan didukung dengan tampilan layar berisi slide power point. Materi yang disampaikan terkait dengan penyakit DM dan hipertensi, mengikuti pengertian. gejala penyakit, faktor resiko, dan berbagai jenis tanaman dan cara penggunaannya untuk pengobatan DM dan hipertensi. Tampilan slide digunakan untuk membantu peserta untuk memperoleh visualisasi yang disampaikan oleh pemateri. Penyampaian materi dengan menggunakan metode ceramah ini disampaikan oleh 2 orang pemateri, masingmasing menyampaikan mengenai penyakit DM dan hipertensi.

Tahap kedua adalah pemberian materi melalui brosur. Penyampaian brosur dilakukan saat akan memasuki sesi diskusi. Brosur dibagikan kepada setiap peserta. Informasi yang dicantumkan 
dalam brosur meliputi pengertian penyakit DM dan hipertensi, gejala penyakit, faktor resiko, jenis tanaman yang dapat digunakan untuk pengobatan DM dan hipertensi serta terapi non farmakologis untuk penyakit DM dan hipertensi. Brosur dicetak menggunakan kertas berwarna serta dalam bentuk yang dapat dilipat sehingga memudahkan untuk disimpan.

c. Diskusi

Sesi diskusi dilakukan untuk melibatkan peserta dalam penyampaian informasi. Peserta dipersilahkan untuk berbagi pengamalaman atau bertanya terkait dengan materi yang disampaikan. Pertanyaan yang masuk, dijawab secara lisan oleh tim pemateri.

d. Post test

Post test dilakukan setelah sesi diskusi dan dilakukan secara tertulis. Pertanyaan yang disampaikan pada post test adalah sama dengan pertanyaan yang diberikan untuk pre-test. Sesi post test digunakan untuk mengukur tingkat pemahaman peserta terhadap materi yang disampaikan.

e. Pengolahan data

Hasil pre-test dan post test peserta penyuluhan kemudian dikumpulkan dan dilakukan penilaian. Nilai pre-test dan post test kemudian dihitung skor totalnya, dan dibandingkan antara nilai sebelum dan sesudah pemberian materi dengan uji t berpasangan (taraf kepercayaan 95\%).

\section{Hasil dan Pembahasan}

Upaya peningkatan pemahaman masyarakat Kampung Windan tentang pemanfaatan tanaman untuk pengobatan DM dan hipertensi dilakukan melalui kegiatan penyuluhan yang diselenggarakan bersama dengan kegiatan PKK rutin setiap bulan. Kegiatan ini berlangsung di rumah salah satu warga dengan peserta ibu-ibu PKK Kampung Windan RT 1 RW8. Kegiatan dibuka oleh pengurus PKK Kampung Windan dan dilanjutkan dengan kegiatan rutin PKK. Penyuluhan terkait pemanfaatan tanaman untuk pengobatan DM dan hipertensi ditempatkan sebagai acara inti pada kegiatan ini.

Tahapan pertama sebelum diberikan materi dilakukan pre-test yang digunakan sebagai baseline terkait pengetahuan peserta. Pre-test diberikan dalam bentuk multiple choice questions (MCQ) dengan 10 (sepuluh) bertanyaan terkait penyakit DM dan hipertensi. Aspek yang ditanyakan meliputi penyebab penyakit, gejala penyakit, faktor resiko, terapi non farmakologi dan pengetahuan terkait tanaman yang dapat digunakan untuk pengobatan DM dan hipertensi. Suasana pelaksanaan pre-test dapat dilihat pada Gambar 1. Hasil pre-test peserta diperoleh skor rata-rata sebesar $8,2 \pm 1,88(\mathrm{n}=23)$.

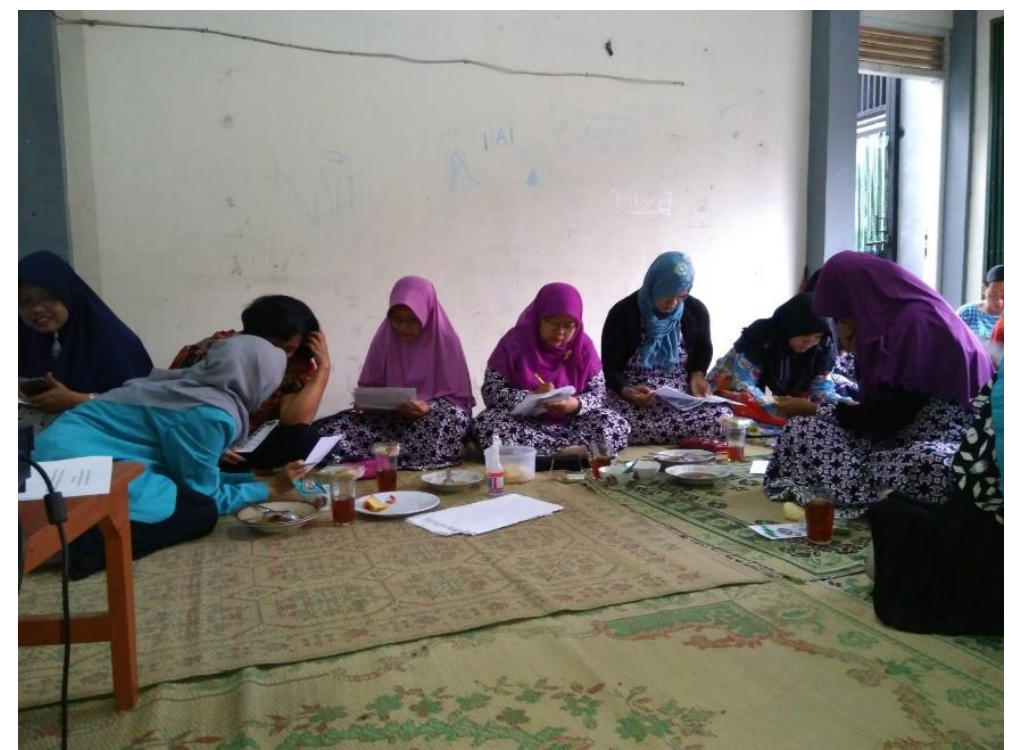

Gambar 1. Suasana pre-test untuk materi diabetes melitus dan hipertensi 
Materi diberikan dengan metode ceramah dan tampilan slide power point. Materi yang disampaikan terkait dengan penyakit DM dan hipertensi dan disampaikan oleh 2 orang pemateri. Materi terkait penyakit DM menyampaikan tentang pengertian penyakit DM, faktor resiko, gejala penyakit, terapi non farmakologi untuk DM dan tanaman yang dapat digunakan untuk penyakit DM. Pada materi pertama terkait dengan DM, disampaikan beberapa gejala terkait dengan penyakit DM yaitu rasa haus yang berlebihan, sering buang air kecil terutama di malam hari, rasa kelelahan, dan penglihatan yang menurun atau kabur. Pasien dikategorikan menjadi prediabetes dan diabetes. Seseorang dinyatakan dalam keadaan prediabetes jika kadar gula puasa (GDP) antara 100-125 mg/dl dan diabetes jika GDB diatas $126 \mathrm{mg} / \mathrm{dl}$. Penyakit DM dapat dibedakan menjadi DM tipe 1, tipe 2 dan diabetes gestasional. Untuk DM tipe 1, tidak dapat dihindari karena merupakan kelainan tubuh akibat kegagalan produksi insulin oleh pancreas. Sedangkan untuk DM tipe 2, dapat dikenali sejak awal dan dapat di hambat atau diperlambat progressnya untuk menghindari adanya komplikasi. Pada diabetes gestasional, yang terjadi pada saat kehamilan, dapat memiliki resiko untuk menjadi diabetes tipe 2, jika tidak diperhatikan dengan baik. Untuk itu, perlu dilakukan pemantauan pada penderita DM gestasional (Barhum, 2019).

Pada materi juga disampaikan terkait faktor resiko tinggi untuk DM yaitu adanya kondisi prediabetes. Seseorang dengan kondisi prediabetes dapat berkembang menjadi kondisi DM dengan progress perkembangan 6-10\% jika tidak dilakukan pemantauan dengan baik. Faktor resiko untuk penyakit diabetes sendiri adalah usia lanjut, kegemukan, kurang aktivitas fisik, kurang mengkonsumsi buah dan sayur, keturunan dan adanya penyakit hipertensi. Penelitian oleh Soewondo \& Pramono, (2011) menyebutkan bahwa kondisi prediabetes di Indonesia banyak ditemukan pada wanita (61.6\%) dengan profesi ibu rumah tangga (27.3\%) dan usia antara 38-47 tahun dengan tingkat sosial ekonomi tinggi (62.8\%).

Materi tentang tanaman untuk pengobatan DM yang disampaikan pada penyuluhan ini adalah daun sambiloto, daun salam, temulawak dan buah mengkudu. Beberapa literatur menyebutkan bahwa ekstrak daun sambiloto yang memiliki rasa pahit memiliki kandungan senyawa andrografolid, flavonoid, andrografin, panikulida dan penikulin. Senyawa-senyawa ini disebutkan memiliki aktivitas untuk meningkatkan penggunaan glukosa dalam otot tikus yang diinduksi untuk menderita diabetes dengan mekanisme stimulasi transporter GLUT-4. Tanaman ini juga digunakan di berbagai negara sebagai senyawa antihiperglikemia (Adha et al., 2019; Salehi et al., 2019). Selain daun sambiloto, daun salam, temulawak dan buah mengkudu juga disebutkan dalam beberapa literatur, biasa digunakan pada pasien diabetes di beberapa negara untuk pengobatan. Mayoritas penggunaan tanaman ini adalah dengan cara direbus dan diminum setelah makan (Salehi et al., 2019; Widyawati et al., 2015). Pada kegiatan ini, disampaikan mengenai cara penggunaan tanaman ini untuk pengobatan DM sebagai terapi penunjang, yaitu dengan cara merebus bahan-bahan tersebut menggunakan air dan diminum setelah makan. Selain terapi untuk DM, juga disampaikan bagaimana cara mencegah terjadinya komplikasi akibat penyakit DM. Sesuai dengan panduan dari P2PTM Kemenkes RI, komplikasi pada penyakit diabetes dapat dicegah dengan pengobatan yang teratur, mengkontrol kadar gula darah dengan baik, makan makanan sehat dengan sayur dan buah, mengurangi lemak, beraktivitas fisik secara teratur, mewaspadai adanya infeksi kulit serta melakukan pemeriksaan penglihatan secara teratur (Direktorat P2PTM Kemenkes Republik Indonesia, 2019).

Materi kedua yang disampaikan adalah terkait hipertensi. Pada bagian ini disampaikan terkait pengertian hipertensi dengan gejala tingginya tekanan darah (lebih dari 140/90 mmHg). Hipertensi merupakan penyakit kronis yang dapat meningkatkan resiko adanya penyakit ikutan yang lain yaitu ginjal, kebutaan, serangan jantung hingga stroke. Faktor resiko terjadinya hipertensi akan meningkat dengan adanya obesitas, stress, hipokalemia, konsumsi garam berlebih, kekurangan vitamin D serta bertambahnya usia (diatas 40 tahun) (Hughes et al., 2013; Tabassum \& Ahmad, 2011). Sebagian besar penderita hipertensi tidak merasakan gejala sehingga penyakit ini sering disebut sebagai silent killer. Tetapi ada beberapa pasien yang mengalami keluhan antara 
lain sakit kepala, gelisah, jantung berdebar, pusing, penglihatan kabur, rasa sakit di dada dan mudah lelah (Direktorat P2PTM Kemenkes Republik Indonesia, 2018).

Pada materi kedua ini, disampaikan mengenai tanaman yang dapat berguna untuk pengobatan hipertensi. Penggunaan tanaman untuk pengobatan hipertensi ini banyak ditemukan pada negaranegara berkembang terkait dengan tingkat ekonomi dan social yang rendah, tetapi penggunaan tanaman untuk terapi hipertensi ini juga telah banyak diteliti sehingga dapat dipercaya secara saintifik (Tabassum \& Ahmad, 2011). Jenis tanaman yang digunakan untuk hipertensi antara lain buah mengkudu, daun salam, kunyit dan bawang putih. Mengkudu merupakan tanaman yang diketahui memiliki khasiat untuk menurunkan tekanan darah mulai dari akar, daun hingga buah. Penelitian menyebutkan bahwa di dalam daun dan buah mengkudu terdapat kandungan senyawa scopoletin dan rutin yang dapat menurunkan tenanan darah sebesar $25 \%$ pada hewan uji (Almeida et al., 2019). Efek antihipertensi pada daun salam juga disebutkan pada penelitian yang dilakukan oleh Ribeiro et al., (2014) dimana daun salam disebutkan dapat menurunkan tekanan darah dan detak jantung pada hewan uji dengan mekanisme penghambatan influk kalsium ekstraseluler. Kunyit juga termasuk dalam tanaman rempah yang dipercaya dapat digunakan untuk mengobati hipertensi dengan mekanisme antioksidan, antiinflamasi, interferensi ion kalsium, aktivasi reseptor alpha adrenergic dan penghambatan renin-angiotensin. Kunyit biasa digunakan sebagai bumbu masakan (Leong, 2018). Penggunaan bawang putih sebagai antihipertsi secara klinis direview dalam artikel dari Ried \& Fakler (2014). Dalam artikel ini disebutkan bahwa bawang putih berpotensi sebagai bahan yang dapat menurunkan tekanan darah melalui induksi relaksasi otot pembuluh darah dan menurunkan tekanan darah dengan kandungan polisulfida yang terdapat pada bawang putih (Ried \& Fakler, 2014). Pada kegiatan penyuluhan, juga disampaikan bagaimana melakukan terapi non farmakologi untuk menghindari terjadinya hipertensi yaitu dengan penurunan berat badan, mengkonsumsi sayuran, buah dan makanan rendah lemak, olahraga ringan secara rutin minimal 150 menit per minggu, tidak merokok dan menghindari minuman beralkohol (Barhum, 2019). Suasana saat pemberian materi terkait pengobatan DM dan hipertensi dapat dilihat pada Gambar 2.

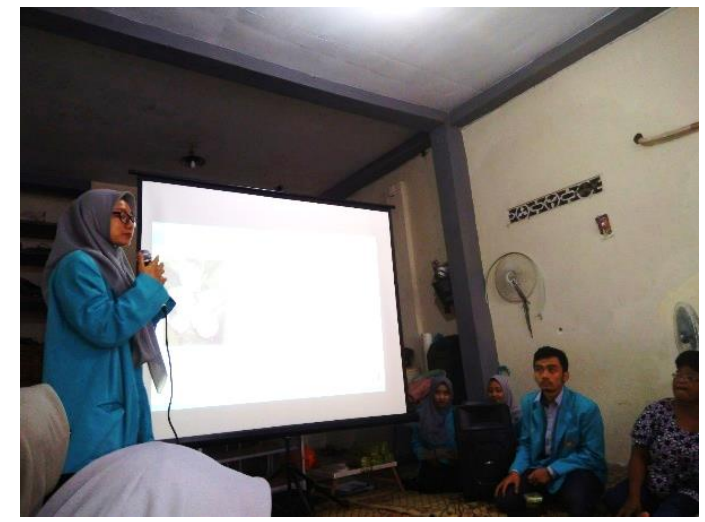

(a)

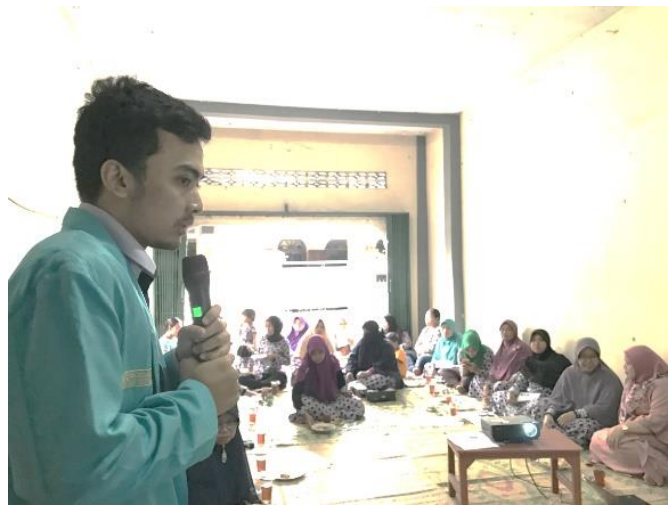

(b)

Gambar 2. Penyampaian Materi Penyuluhan terkait tanaman untuk penyakit (a) Diabetes Mellitus dan (b) Hipertensi.

Setelah dilakukan pemberian materi dengan metode ceramah, juga dilakukan pemberian materi melalui brosur yang dibagikan pada peserta. Isi materi yang disampaikan melalui brosur, merupakan ringkasan materi yang disampaikan dengan metode ceramah (Gambar 3). pemberian brosur ini bertujuan agar materi yang disampaikan dapat disimpan sebagai catatan oleh peserta dan dapat diberikan pada anggota keluarga di rumah sehingga jangkauan informasi yang disampaikan saat acara menjadi lebih luas. Brosur dipercaya sebagai alat untuk menyebarluaskan informasi. Tetapi terkadang penyebaran informasi melalui brosur terkendala oleh tidak dibacanya 
informasi yang tertera pada brosur (Silvana \& Rohanda, 2017) sehingga tampilan brosur harus menarik dengan penggunaan warna dan materi yang ringkas sehingga mudah dipahami.

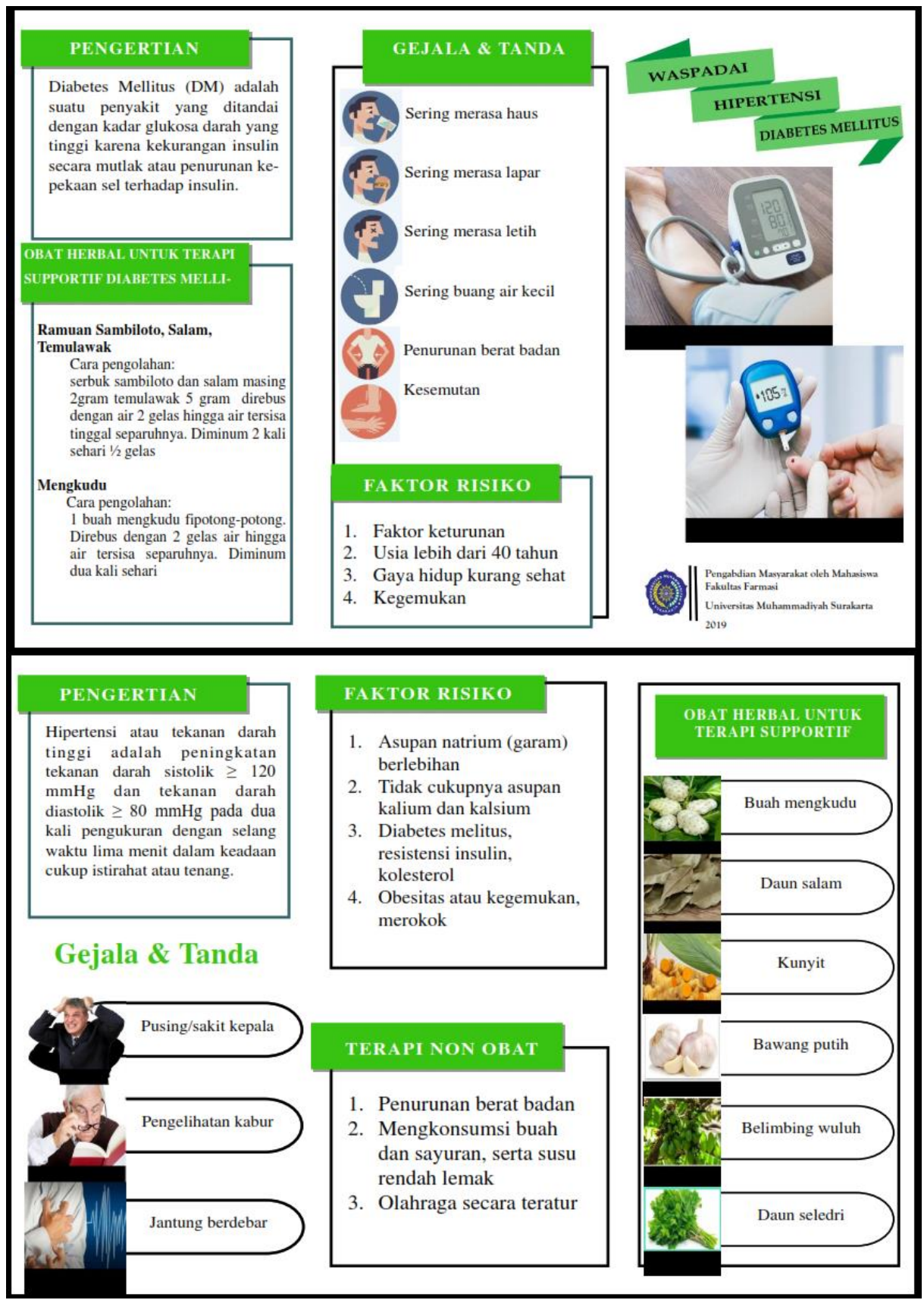

Gambar 3. Brosur berisi materi tentang penyakit diabetes melitus dan hipertensi serta tanaman obat yang dapat digunakan untuk pengobatan.

Sebagai bagian dari pemberian materi, dibuka sesi diskusi dan tanya jawab. Sesi diskusi dimaksudkan agar peserta dapat ikut terlibat aktif terkait dengan materi yang disampaikan sehingga tingkat pemahaman terhadap materi yang disampaikan menjadi lebih baik. Metode diskusi diharapkan dapat menciptakan interaksi antar individu bai kantar sesama peserta atau peserta dnegan pemateri. Diskusi antar peserta juga dapat merangsang daya pikir dikalangan peserta untuk lebih memahami materi yang diberikan. Beberapa pertanyaan dari peserta muncul pada sesi ini seperti yang terangkum pada Tabel 1. Pertanyaan yang muncul dijawab oleh 
pemateri. Beberapa peserta juga menceritakan pengalaman pribadi mereka dalam mengatasi penyakit DM dan hipertensi secara non farmakologi.

Tabel 1. Pertanyaan dan jawaban yang ada pada sesi diskusi kegiatan penyuluhan penggunaan tanaman sebagai terapi penunjang diabetes mellitus dan hipertensi.

\begin{tabular}{|c|c|}
\hline No & Pertanyaan \\
\hline 1 & $\begin{array}{l}\text { Jika suami menderita diabetes mellitus } \\
\text { dengan kadar gula darah } 590 \mathrm{mg} / \mathrm{dL} \\
\text { dan mengkonsumsi rebusan air sayuran } \\
\text { pare menjadi drop, bagaimana } \\
\text { solusinya? }\end{array}$ \\
\hline 2 & $\begin{array}{l}\text { Apakah gejala dari penyakit itu hanya } \\
\text { satu? }\end{array}$ \\
\hline & $\begin{array}{l}\text { Apakah jika cara mengkonsumsi obat } \\
\text { herbal berbeda, misal kunyit langsung } \\
\text { dimakan, apakah ada akibatnya? }\end{array}$ \\
\hline
\end{tabular}

4. Antara garam kasar dan garam halus, mana yang lebih baik untuk hipertensi?

5. Bagaimana cara pengolahan kunyit dan bawang putih untuk hipertensi?

\begin{abstract}
Kadar gula darah tidak boleh terlalu rendah. Obat harus tetap dikonsumsi untuk menjaga kadar gula dan rebusan air sayuran pare dikurangi supaya kadar gula darah tidak terlalu rendah.
\end{abstract}

Biasanya gejala itu tidak hanya satu, akan tetapi dapat berkesinambungan.

Cara pengelolaan mempengaruhi khasiat. Pengolahan sangat tergantung dari sifat zat berkhasiat apa yang akan diambil dari suatu herbal atau tanaman.

Terdapat banyak jenis garam, tetapi kandungan garamnya sama, yang membedakan adalah terdapat kandungan yodium atau tidak. Garam yang sudah diolah mengandung yodium, sehingga sudah layak dikonsumsi.

Ada banyak cara, yaitu bisa ditambahkan ke masakan, bisa dibuat jamu, atau dibuat jus. Prinsip utamanya adalah pengambilan zat aktifnya. Ada zat aktif yang larut air, sehingga cara pengolahannya direbus, ada yang langsung dibuat jus. Sehingga ada banyak cara untuk mengambil zat aktif dari tanaman herbal.

Tahap selanjutnya dari kegiatan ini adalah pengukuran pemahaman peserta penyuluhan dengan memberikan post test. Butir pertanyaan post test sama dengan pertanyaan pre-test, sehingga diharapkan peserta dapat menjawab dengan benar pertanyaan yang sebelumnya tidak diketahui. Acara kemudian ditutup dengan pembagian door prize bagi peserta penyuluhan.

Hasil penilaian post test diperoleh skor rata-rata peserta adalah 9.1 \pm 1.60 . Untuk melihat signifikansi peningkatan pemahaman peserta dengan adanya pemaparan materi, dilakukan uji ttest berpasangan untuk melihat adanya perbedaan nilai antara sebelum dan sesudah pemberian materi. Hasil analisis statistik menunjukkan nilai $\mathrm{p}<0.05$ sehingga dapat dikatakan adanya pemberian materi melalui metode ceramah dan pemberian informasi melalui brosur dapat meningkatkan pemahaman peserta terkait dengan materi yang diberikan. Sehingga dapat dikatakan bahwa penggunaan kedua metode ini untuk menyampaikan informasi adalah efektif. Pada penelitian yang dilakukan oleh Aminuddin \& Bong (2018) disebutkan bahwa pemberian informasi melalui brosur sebenarnya lebih efetkif dibandingkan ceramah. Pada penelitian ini, digunakan kedua metode tersebut, sehingga diharapkan tingkat pemahaman peserta penyuluhan 
menjadi lebih tinggi. Kekurangan pada kegiatan ini adalah tidak dilakukannya pemetaan terhadap sebaran peserta dari segi usia, pekerjaan dan tingkat pendidikan, sehingga tidak dapat diketahui dengan pasti apakah tingkat pengetahuan ini murni berasal pemberian informasi berupa ceramah dan brosur atau berasal dari pengetahuan yang sebelumnya telah dimiliki oleh peserta.

Dari hasil pengukuran pemahaman peserta tentang penggunaan tanaman obat untuk pengobatan DM dan hipertensi, kegiatan ini menunjukkan manfaat untuk memberikan pengetahuan pada peserta penyuluhan untuk lebih mengenali penyakit dan pengobatan DM dan hipertensi. Harapannya dengan pemberian informasi ini akan dapat mendorong masyarakat untuk mengikuti gaya hidup sehat dan seimbang serta mengikuti pengobatan yang dianjurkan agar terhindar dari komplikasi akibat penyakit DM dan hipertensi.

\section{Simpulan}

Kegiatan pemberian informasi melalui metode ceramah dan brosur secara efektif dapat meningkatkan pemahaman peserta yaitu masyarakat Kampung Windan RT 1 RW 8 tentang penyakit diabetes mellitus (DM) dan hipertensi dan memberikan informasi terkait tanaman yang dapat digunakan sebagai terapi penyakit DM dan hipertensi. Efektifitas pemberian informasi dengan metode penyuluhan dan pemberian brosur ini diukur berdasarkan perbedaan yang bermakna $(\mathrm{p}<0,05)$ antara skor pre-test dan post test.

\section{Persantunan}

Terimakasih disampaikan kepada Ketua RT 1, RW 8, Kampung Windan yang telah memberikan ijin terlaksananya kegiatan ini. Ucapan terimakasih juga disampaikan kepada Universitas Muhammadiyah Surakarta yang telah memebrikan pendanaan untuk kegiatan ini melalui skema Pengembangan Individual Dosen (PID).

\section{Referensi}

Adha, S. A., Febriyanti, R. M., \& Milanda, T. (2019). Review : Potensi Sambiloto Sebagai Obat Antidiabetes Berbasis Herbal a Review : Potential of Sambiloto As Herbal Based Antidiabetic Medicine. Medical Sains, 4(1), 7-12.

Almeida, É. S., de Oliveira, D., \& Hotza, D. (2019). Properties and Applications of Morinda citrifolia (Noni): A Review. Comprehensive Reviews in Food Science and Food Safety. https://doi.org/10.1111/1541-4337.12456

Aminuddin, M., \& Bong, F. S. (2018). Efektifitas Metode Ceramah dan Metode Leaflet/Brosur terhadap Tingkat Pemahaman Ibu-Ibu Post Partum tentang ASI Ekslusif. Jurnal Kesehatan Pasak Bumi Kalimantan ( Publikasi Artikel Scince Dan Art Kesehatan, Bermutu, Unggul, Manfaat Dan Inovatif), 1(2), 96-103.

Barhum, L. (2019). Diabetes and hypertension: What is the relationship? Medical News Today. https://www.medicalnewstoday.com/articles/317220

Cheung, B. M. Y., \& Li, C. (2012). Diabetes and hypertension: Is there a common metabolic pathway? Current Atherosclerosis Reports, 14(2), 160-166.

https://doi.org/10.1007/s11883-012-0227-2

Direktorat P2PTM Kemenkes Republik Indonesia. (2018). Gejala Hipertensi. http://p2ptm.kemkes.go.id/infographic-p2ptm/hipertensi-penyakit-jantung-dan-pembuluhdarah/gejala-hipertensi

Direktorat P2PTM Kemenkes Republik Indonesia. (2019). Bagaimana mencegah komplikasi Diabetes? - Direktorat P2PTM. http://p2ptm.kemkes.go.id/infographic-p2ptm/penyakit- 
diabetes-melitus/bagaimana-mencegah-komplikasi-diabetes

Hughes, G. D., Aboyade, O. M., Clark, B. L., \& Puoane, T. R. (2013). The prevalence of traditional herbal medicine use among hypertensives living in South African communities. BMC Complementary and Alternative Medicine, 13. https://doi.org/10.1186/1472-6882$13-38$

Peraturan Menteri Dalam Negeri Republik Indonesia Nomor 36 Tahun 2020, Pub. L. No. 36 tahun 2020, 1 (2020).

Leong, X. F. (2018). The spice for hypertension: Protective role of Curcuma longa. Biomedical and Pharmacology Journal, 11(4), 1829-1840. https://doi.org/10.13005/bpj/1555

Li, G. Q., Kam, A., Wong, K. H., Zhou, X., Omar, E. A., Alqahtani, A., Li, K. M., Razmovskinaumovski-, V., \& Chan-, K. (2012). Chapter 28: Herbal Medicines for the Management of Diabetes. In Diabetes: An Old Disease. a New Insight (pp. 396-413).

Neamsuvan, O., Komonhiran, P., \& Boonming, K. (2018). Medicinal plants used for hypertension treatment by folk healers in Songkhla province, Thailand. Journal of Ethnopharmacology, 214, 58-70. https://doi.org/10.1016/j.jep.2017.11.032

Pawiro, M. (2019). Metode Pembelajaran: Pengertian, Macam-Macam, dan Tujuannya. https://www.maxmanroe.com/vid/umum/metode-pembelajaran.html

Ramadhan, M. N., Niaga, A., Malang, P. N., \& Draw, C. (2018). Pembuatan Brosur Sebagai Media Promosi Dengan Menggunakan Coreldraw Pada Nod Doctrine. 377-382.

Ribeiro, R. M., Pinheiro Neto, V. F., Ribeiro, K. S., Vieira, D. A., Abreu, I. C., Silva, S. D. N., Cartágenes, M. D. S. D. S., Freire, S. M. D. F., Borges, A. C. R., \& Borges, M. O. D. R. (2014). Antihypertensive effect of syzygium cumini in spontaneously hypertensive Rats. Evidence-Based Complementary and Alternative Medicine, 2014. https://doi.org/10.1155/2014/605452

Ried, K., \& Fakler, P. (2014). Potential of garlic (Allium sativum) in lowering high blood pressure: Mechanisms of action and clinical relevance. Integrated Blood Pressure Control, 7, 71-82. https://doi.org/10.2147/IBPC.S51434

Salehi, B., Ata, A., Anil Kumar, N. V, Sharopov, F., Ramírez-Alarcón, K., Ruiz-Ortega, A., Abdulmajid Ayatollahi, S., Valere Tsouh Fokou, P., Kobarfard, F., Amiruddin Zakaria, Z., Iriti, M., Taheri, Y., Martorell, M., Sureda, A., Setzer, W. N., Durazzo, A., Lucarini, M., Santini, A., Capasso, R., ... Sharifi-Rad, J. (2019). Antidiabetic Potential of Medicinal Plants and Their Active Components. https://doi.org/10.3390/biom9100551

Salleh, N. A. M., Ismail, S., \& Ab Halim, M. R. (2016). Effects of Curcuma xanthorrhiza Extracts and Their Constituents on Phase II Drug-metabolizing Enzymes Activity. Pharmacognosy Research, 8(4), 309-315. https://doi.org/10.4103/0974-8490.188873

Silvana, T., \& Rohanda, H. (2017). Efektifitas Penggunaan Media Komunikasi Dalam Rangka Sosialisasi Program GPMB (Gerakan Pembinaan Masyarakat Baca) Di Jawa Barat. Commed : Jurnal Komunikasi Dan Media, 2(1), 25. https://doi.org/10.33884/commed.v2i1.235

Soewondo, P., \& Pramono, L. A. (2011). Prevalence, characteristics, and predictors of prediabetes in Indonesia. Medical Journal of Indonesia, 20(4), 283-294. 
Tabassum, N., \& Ahmad, F. (2011). Role of natural herbs in the treatment of hypertension. Pharmacognosy Reviews, 5(9), 30-40. https://doi.org/10.4103/0973-7847.79097

Tayyab Akhtar, M., Syakir Bin Mohd Sarib, M., Safinar Ismail, I., Abas, F., Ismail, A., Hj Lajis, N., \& Shaari, K. (2016). Anti-Diabetic Activity and Metabolic Changes Induced by Andrographis paniculata Plant Extract in Obese Diabetic Rats. Molecules, 21(1068). https://doi.org/10.3390/molecules21081026

Warnars, H. L. H. S. (2006). Efektifitas Teknologi Informasi Dalam Proses Belajar Mengajar pada Universitas Budi Luhur. National Seminar Information Technology Application, 2006(17 Juni 2006), 23-26.

Widyawati, T., Purnawan, W. W., Atangwho, I. J., Yusoff, A., Ahmad, M., \& Zaini Asmawi, M. (2015). Anti-Diabetic Activity of Syzygium Polyanthum (Wight) Leaf Extract, the Most Commonly Used Herb Among Diabetic Patients in Medan, North Sumatera, Indonesia. International Journal of Pharmaceutical Sciences and Research IJPSR, 6(4), 1698-1704. https://doi.org/10.13040/IJPSR.0975-8232.6(4).1698-04

\section{(c) (1) $\Theta(\Theta$}

(C) 2021 by the authors. Submitted for possible open access publication under the terms and conditions of the Creative Commons Attribution (CC-BY-NC-ND) license (http://creativecommons.org/licenses/by/4.0/). 